Journal of Jazz Studies vol. 10, no. 2, pp. 198-202 (Winter 2014-2015)

\title{
Lee Morgan: A Retrospective
}

\author{
Howard Sterling Fulcher
}

My cousin, Lester Hinton introduced me to Delightfulee: The Life and Music of Lee Morgan, a book by Jeffery S. McMillan. His work inspired me to look back and bring forward some reflections of my own. Over 40 years ago my path crossed with Lee's and I'd like to share that encounter with you.

My interest in Jazz dates back to the early 1950s. My dad, Joseph Fulcher, Sr. and my uncle Paul Hinton were the first jazz enthusiasts who encouraged my love of the music. My dad and mom Ida were both organists in churches in Paterson, New Jersey. Dad often brought home new recordings by Erroll Garner, Ahmad Jamal and others. Uncle Paul had one of the first Hi-Fi component sets in town and quite a collection of big band recordings. Among those were Maynard Ferguson's Around the Horn, John Lewis' Grand Encounter: $2^{\circ}$ East $-3^{\circ}$ West, with musicians from both coasts and similar recordings from the period. When Uncle Paul upgraded to STEREO it was a turning point in our lives. Not only were we treated to high fidelity; now we had two channels and two speakers!

In 1956, dad started taking my older brother Joe and I to shows in and around New York City. The Apollo was our favorite spot but we also went to the The Brooklyn Fox, The Brooklyn Paramount and, when we were older, Birdland.

Also, in 1956, I remember seeing Lee Morgan with the Dizzy Gillespie Band at the Passaic Capital Theater when Lee was a teen, as I was, but a GREAT $3 \frac{1}{2}$ year age difference. After this I was away to college, in the army for three years and didn't get to see Lee in person again until the late 60s. At Howard University I met and befriended Charles Tolliver, another natural born trumpeter and a pharmacy student as I was. In $1964 \mathrm{I}$ ran into Tolliver performing at a Monday night session at Birdland while my wife and I were on our honeymoon. Fast forward to 1969 and I am sitting at Lee's table at the Port of Call East in New York City where Charles was playing with the Music Inc. group including Stanley Cowell, Cecil McBee and Jimmy Hopps. Morgan remarked about Tolliver's playing, "Wow, and on flueglehorn, too".

During our conversation, I mentioned to Lee that I was putting shows together in my hometown of Paterson, New Jersey. He expressed an interest in 
performing and, indeed soon afterwards, my wife and I ventured to Lee's apartment on the Grand Concourse in the Bronx to conduct business with him and Helen "Morgan." Helen, in fact, signed Lee's name and hers on the check and I gave her a cash deposit for a weekend engagement. I think it was $\$ 500.00$. I was to pay the balance of $\$ 700$ on the last day of the three-day show, which was Mother's Day, Sunday, May 10, 1970.

The venue was a 250-seat club named The Lafayette Playhouse. The entrance was actually on Summer St. and the building still stands, but it is all apartments now. The club was owned by Russell Graddy who is today a prominent businessman in Paterson, and the manager was John Harris. Mr. Harris and I contracted to share any expenses and any profit. Unfortunately the show was a bust since another Paterson group, The Young Men of Paterson, had a bash planned and the New York Knicks were in the playoffs (and eventually won the NBA championship). Plus, Paterson was really a rhythm and blues town, as we found out. Harold Mabern, the pianist in Lee's band, had a transistor radio with him to stay tuned to the Knicks game during each break in the show.

The group that Lee used that weekend was the same one that can be heard on his Live at the Lighthouse album recorded in California two months later. It was Lee on trumpet, Bennie Maupin on reeds, Harold Mabern on piano, Jymie Merritt on bass, and Mickey Roker on drums. The show turned out to be a rehearsal for that recording because the audience was sparse to say the least. I had expected many more people since my show with Charles Tolliver at the same venue had a big draw just two months earlier. Of course an African drum and dance troupe with fashions and stage play were attached on the night that Tolliver's quartet had played.

After Lee's weekend in Paterson, a friend, Doug Hawthorne and I had to hustle up enough money to pay the balance to the band. Lee told me not to worry about his "finder's fee." He said, "Just give me enough to pay my guys." That we did. The following week I went to Slug's, a jazz club in the East Village of New York, to give Lee the $\$ 300$ I had promised. He was shocked to see me with the cash, but I was grateful to him for being so generous. He had an ego, but it was needed in that field. I'd like to point out that this was a gentlemen's agreement and Lee Morgan was indeed a gentleman.

The Tolliver photo was taken by Jim Alexander, a friend and professional photographer who is now based in Atlanta, Georgia. The Lee Morgan photos were taken by Philip Thomas, another friend who had recently come home from a tour in Vietnam. He is now retired from being a Vice President at New Jersey Performing Arts Center (NJPAC) and the director of Symphony Hall both in Newark, New Jersey. 

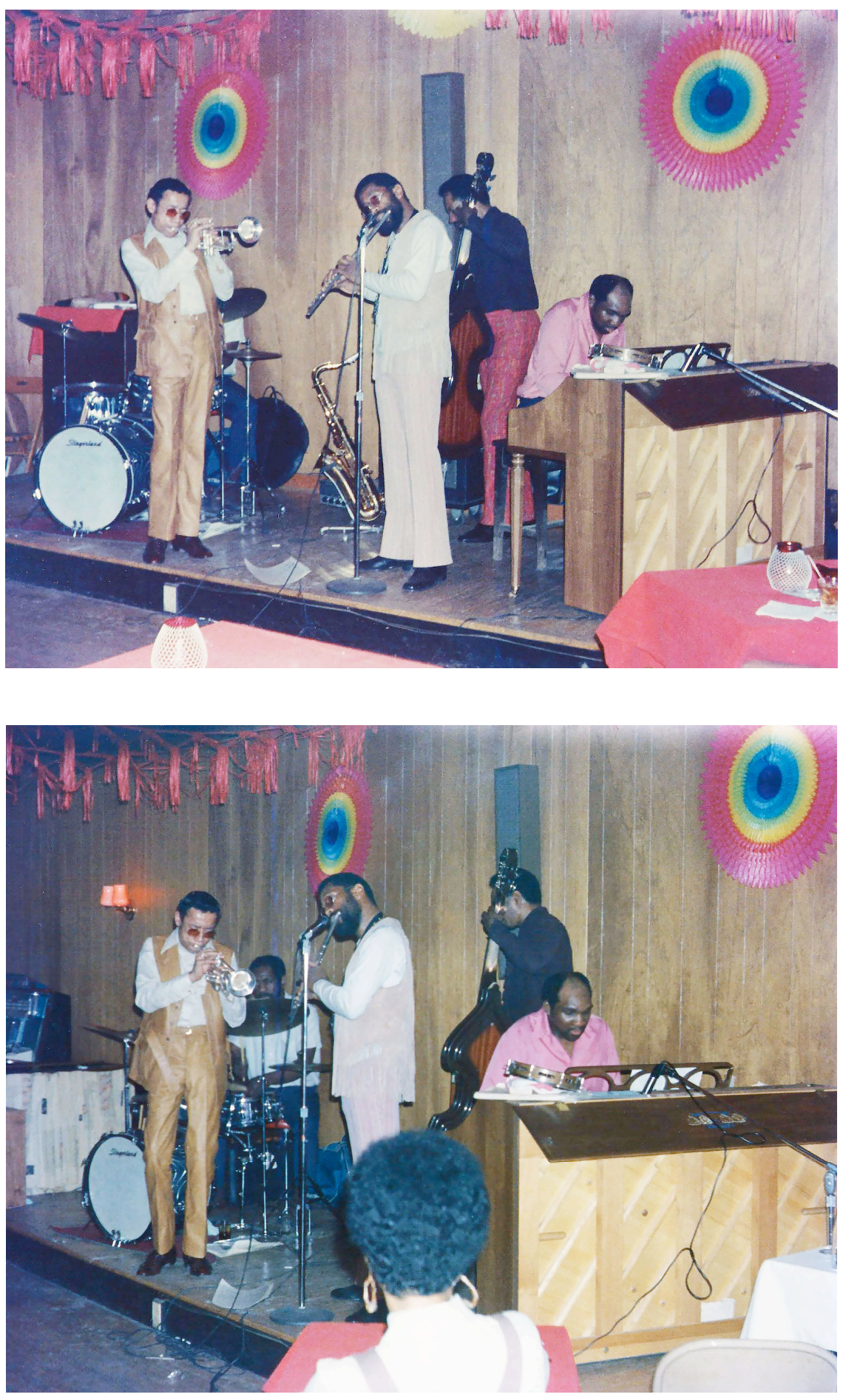


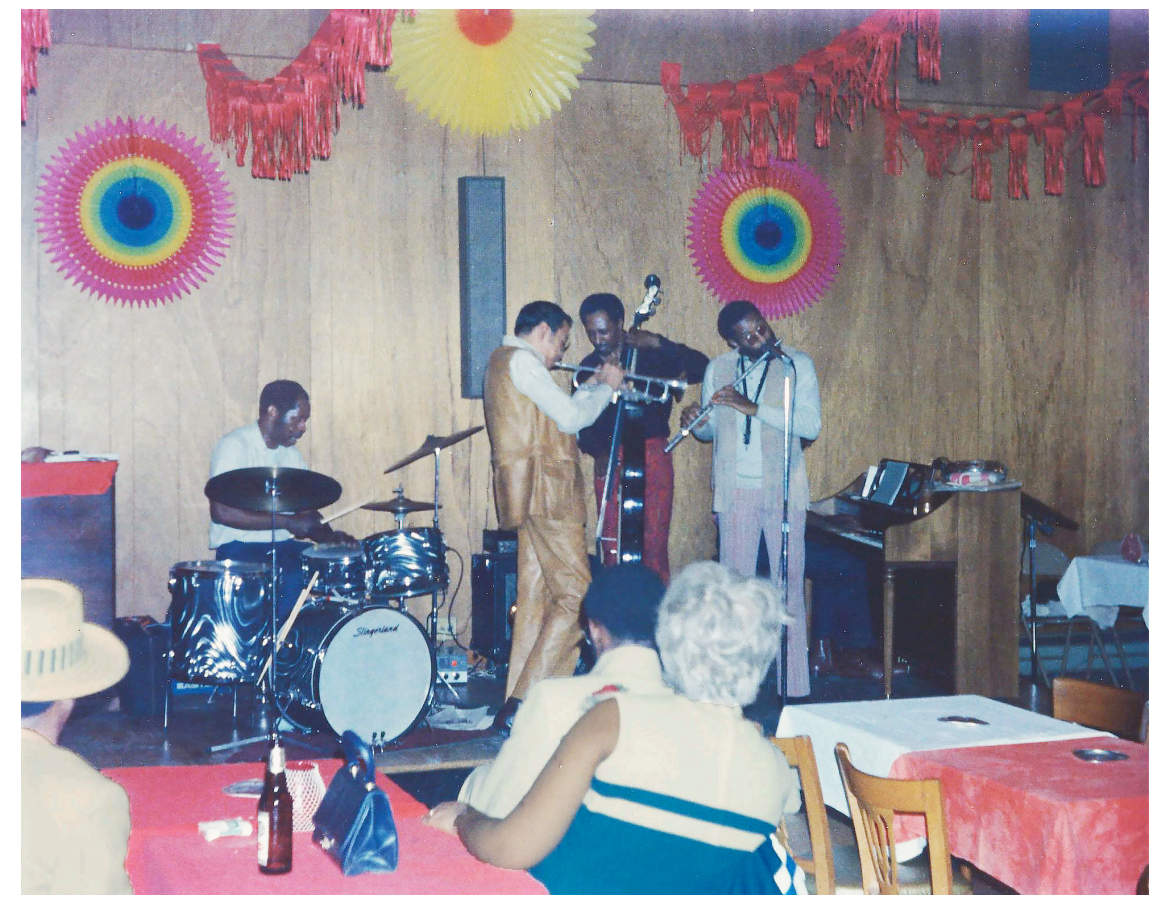

Figure 1-3: Lee Morgan Quintet at The Lafayette Playhouse, Paterson, New Jersey, May 1970. Photo: Philip Thomas. 


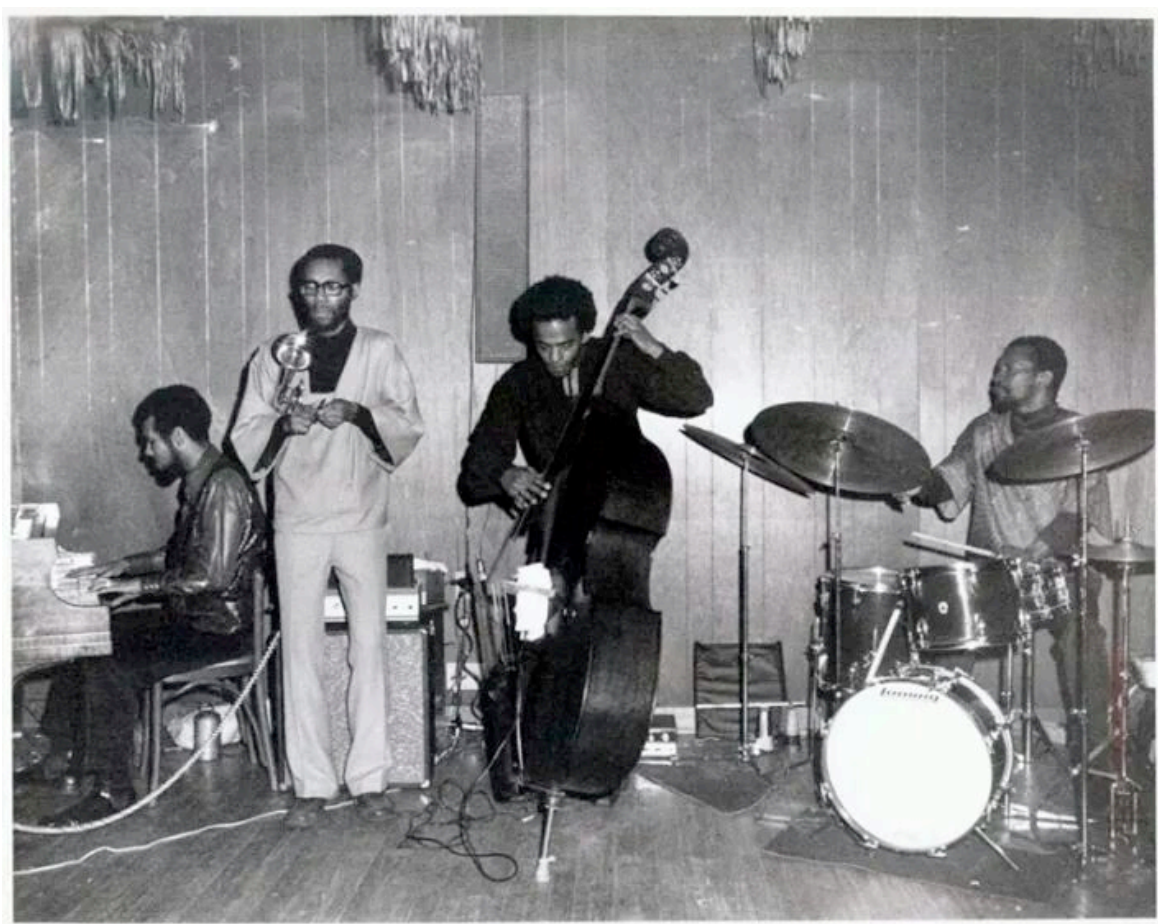

Figure 4. Charles Tolliver Quartet at The Lafayette Playhouse, Paterson, New Jersey, February 1970. Photo: Jim Alexander.

About the Contributor

HoWARD STERLING FULCHER is a retired pharmacist and volunteer docent at the Johnson Victrola Museum in Dover, Delaware.

The Journal of Jazz Studies (JJS) is published by the Institute of Jazz Studies at the Newark campus of Rutgers, The State University of New Jersey. JJS is hosted online by the Rutgers University Libraries at http://jjs.libraries.rutgers.edu. 